\title{
Role Of Video as A Teaching Media to Improve Students' Listening Skills
}

\author{
Ni Komang Tri Lokanita ${ }^{1}$ \\ STKIP Agama Hindu Singaraja, Indonesia \\ komang3lokanita@gmail.com \\ Ni Wayan Monik Rismadewi ${ }^{2}$ \\ STKIP Agama Hindu Singaraja, Indonesia \\ monikmoy@ymail.com \\ Luh Mila Trisna Dewi ${ }^{3}$ \\ STKIP Agama Hindu Singaraja, Indonesia \\ mila@stkipahsingaraja.ac.id
}

\begin{abstract}
The objective of this research is to find out the role of video as a teaching media to improve students' listening skill and to describe how the use of video as a teaching media influences students' motivation during the listening class. The research design of this study is library research or content analysis. The subjects of this research were 5 researches document. The total number of participants in this research was from 166 students. The results of the five researches that have been gathered by the writer showed that video as a teaching media plays important role for students' listening skills. The roles of video as a teaching media to improve students' listening skills are: 1) Video made the students became active in the teaching and learning process, 2) Video made the students became enthusiastic to join the listening class, 3) Video made the learning process became more fun, 4) Video could grab students' attention, and 5) Video could motivate the students to join the listening class. The result of 5 researches showed that students improved their listening skills after being taught by using video.
\end{abstract}

Keywords: listening skill, media, video

\section{INTRODUCTION}

Language is a tool to help people make an interaction to each other. There are many languages in the world, one of them is English. In Indonesia English is a foreign language. Indonesian people are taught English in formal and informal classes. Studying English requires all of the students to mastered 4 skills. They are: Listening, speaking, reading and writing. The fact that in Indonesia English is not a native language makes English quite complicated for them.

One of the complicated skills in learning English is the listening skill. Listening is one of the very important skills in a language. Mastering the listening skill will help the students to do an interaction in their daily life. Listening is an activity that requires the students to understand the speaker's messages. In the listening process there are three aspects that related to each other. Those are 
sender, message, and receiver. Listening is a psychological process because in listening the learner receive messages from the sender, the learner must understand the messages that given by the sender and after they understand the meaning of senders' messages, the learner can give responses. The responses can be verbal or non-verbal.' Tyagi (2013). In addition, the listening skill is the basic skill for the learner before they master speaking skills. The learner must understand the spoken language that they hear. Therefore, listening is very important in a language because by listening the learner will get many inputs for the learners. Listening also has an important role in developing learners' language knowledge. Rost, in Ahmadi (2016). From Tyagi and Rost in Ahmadi explanation we can conclude that listening is the basic skill that the students must master because listening plays an important role in the students' daily life. The listening process requires the students to understand the speaker's messages and be able to respond to the speakers. Mastering listening skills will help the students to communicate very well.

However, based on the research that the writer has gathered, the five researchs showed that Indonesian students of senior high school had problems with listening skills. They found that listening is difficult for them. The factor that made listening difficult for them was because they had limited vocabulary and the speakers' accents made the listening skill were not interesting for them, the teacher taught listening orally by her/himself. According to Darti and Asmawati (2017) there are two factors that affect students listening skills. They are:

\section{A. Listening problem related to the content of the listening text}

1. Problems pertinent to unfamiliar words

2. Problems pertinent to poor grammar

3. Problems pertinent to understand every single word in the text

4. Problems pertinent length of spoken text

5. Problems pertinent to interpret the meaning of the spoken text

6. Problems pertinent fatigue when listen long spoken texts

7. Problems pertinent to unfamiliar topics

8. Problem pertinent to use reduced form

9. Problems pertinent long conversations

10. Problems pertinent basic background knowledge

B. Listening Problems Related to the Listener

1. Problems pertinent to inability of understanding listening

2. Problems pertinent to anxiety

3. Problems pertinent to the unclear pronunciation

4. Problems pertinent intonation of the speaker

5. Problems pertaining to use signal words

6. Problems pertinent to lose focus when get an expected answer

7. Problems pertinent to the use of unknown words

8. Problems pertinent to infer meaning 
9. Problems pertinent unable to concentrate when answer and listen at the same time

10. Problems pertinent to hear new words

11. Problems pertinent to recognize the word

12. Problems pertinent to predict what would come next

13. Problems pertinent to memory

14. Problems pertinent to question

15. Problems Pertinent Lack of Transcripts

There are many ways to solve listening problem that can be used by the teacher. In this study the writer explains a way to solve the listening problems that can help the teacher to improve the students' listening skills. Teaching English, especially listening skills in this country which use English as a foreign language requires the teacher to be creative. The teacher can prepare teaching media to make the class more interesting. Teaching media has important role in listening process; a great teaching media can stimulate and encourage the students to participate during the learning process. Heinich in Kamilah (2013). From all kinds of media, video is a great media to be applied in the classroom because video can divert students' attention especially in listening class.

Using video as a teaching media is more effective than other types of teaching media because by using video in teaching listening the students will use their two sensory at the same time in listening class. The sensory are sound and sight. Harmer in Kamilah (2013). By using video as a teaching media can motivate the students in listening because video provides an interesting picture and sound.

According to Rismawati (2017) using video can involves the students in the learning process. There are many of advantages of using video to teach English. There are:

1. Increasing memory of content and understanding

2. Video can make the learning process more interesting

3. Create memorable visual image

4. Energize or relax students for learning exercise

5. Audios backed with videos motivate the students to pay attention and listen.

Based on the explanation above, the writer conducted library research or content analysis to make a review on the role of video as a teaching media to improve students' listening skills and how the video influence students' motivation during the listening class. This research gathered five researches as data sources. The writer made a review from those researches. All of the researches used video as a teaching media to improve the students' listening skills. From the five researches the writer could find out whether the video was effective for the students or not.

\section{METHOD}

This study used library research or content analysis as research design because the writer gathered all of the data from five documents. According to Cole 
in Showcat (2017) library research or content analysis is the study of recorded human communication such as dairy entries, books, newspapers, videos, text message, Facebook update, etc. In other word library research is a study of what being said, written, and recorded.

The writer collected five researches as data sources. The total participants in this study were 166 students. The research instrument of this study was the writer herself. Since this study used library research or content analysis so the data that the writer used was secondary data.

The writer used qualitative as method of analyzing the data. According to Miles and Huberman in Sugiyono (2009:246) there are three steps in analyzing data in qualitative, they are:

\section{Data Collection}

Data collection is a data which is has been collected by the writer. In this study the data were collected by documentation and triangulation. The documentation was journals and articles.

\section{Data Reduction}

The writer collected some data from journals and articles. In this step, the writer selected those data. The writer gathered the important data which is support this study.

\section{Data Display}

In this step the writer displayed the data that has been reduced into descriptive form.

\section{Conclusion drawing/ Verification}

The last step was conclusion drawing/ verification. After the writer analyzed the data, the writer concluded whether this study achieve the purpose of the study or not

\section{FINDINGS \& DISCUSSIONS}

The first data was from Pratama (2018), he conducted classroom action research for his study. He used English movie as a teaching media to improve students' listening skill. Students improve their listening skill after being taught by using English movie. The mean score of pretest cycle one was 72.14 and the mean score of post-test cycle two was 90.28. Pratama (2018) also did observation during the learning process. The result of the observation was the students more active and enthusiastic to follow the listening class. The students could give their idea about the movie and they discuss it with their friend. He also did an interview to the students. From the interview he concluded that students felt joy and enthusiastic learning English through English videos. The students felt that using English movies as teaching media made the lesson more enjoyable and interesting. English movie also motivated the students because the students can understand the material easily. 
The second data was from Riftiningsih (2018). She conducted classroom action research. She used video as a teaching media to improve students listening skills. The students improve their listening skill after being taught by using video, it can be seen from the result of her study. The result was the mean score of pretest cycle one 54.333 and the result of post-test cycle two was 82 . She also did an observation during the implementation of the teaching media. From the observation she found out that the students more interesting and active in the class. The students gave more attention during the learning process.

The third was from Desi Putriani, Muhammad Sukirlan, Dedy Supriyadi (2013). They used video as a teaching media to improve students listening comprehension. Students improve their listening skill after being taught by using video, the result of their study was: mean score of pre-test: 54.84 , mean score of post-test: 72.17 . They also set an indicator of students' activeness, the indicator score was $80 \%$ of the students should be active during the listening class. After they gave some treatment to the students, the students reached the activeness indicator score. $92.59 \%$ students were active in the class.

The fourth data was from Susilowati (2013). She used video as a teaching media to improve students' listening skills. She chose video as a teaching media because she believed that video can improve the students listening skills. The result of the study showed that video improve the students listening skills, it can be seen from the mean score of the pre-test was 61.64. After being taught by video the mean score increases became 81.01. Ana also did an observation during listening class. From the observation showed that video can motivate the students to join the class and video can make the listening class became more interesting for them. The last data was from Purbasari (2017). She used video to improve students' listening skills. The result of her study showed that video can help the students to improve their listening skill. Students gained their score from 79.6 became 82.6. The score proved that video can improve students' listening skills.

\section{CONCLUSION}

Based on the finding and the discussion, it can be concluded that video plays an important role for students' listening skills. It can be seen from the result of the five researches that the writer collected. The results were:

1. Based on the student's perception video is one of the teaching media which makes the learning process more enjoyable and interesting. That makes the students enthusiastic to follow the listening process.

2. Video can make the students more active during the listening class because video can make the students more understand the spoken message

3. Video can grab students' attention because video provides pictures and sound information.

4. It shows that video can improve the students' listening skills. Video makes them understand the listening material. 
5. The students are motivated to join the listening class because of the teaching media which is video. Motivation is an important thing that the students must have; when the students have motivation to join the listening class it makes them try to understand the spoken message. This will help the students to achieve the purpose of listening skill.

Based on the conclusion above, the writer would like to suggest the teachers who has problem in teaching listening skills to use video as a teaching media instead of using audio only because video is one of the best teaching media that can be used by the teacher. Teachers must select the video before they play the video in the classroom. They must think about the duration of the video, they must see whether the video has benefit for the students or not, and before the teachers plays the video would be nice if they give the students basic knowledge about the video. It will make them easier to understand the video.

\section{REFERENCES}

Ahmadi, Seyedeh Masoumeh. (2016). The Importance of Listening Comprehension in Language Learning. International Journal of Research in English Education. 07.

Darti. (2017). Analyzing Students' Difficulties Toward Listening Comprehension. (Thesis). Univesitas Islam Negeri Alauddin Makassar.

Desi P., Muhammad S., Deddy, S. (2013). The Use of video Movie to Improve Students' Listening Comprehension Achievement. (Thesis). Lampung: FKIP Universitas Lampung.

Kamilah, Mardiya. (2013)/ "The Use of Contextual Video to Improve Students" Listening Ability. Journal of English and Education. 1(1): 123.

Pratama, Z. (2018). Improving Students' Listening Skill Through Watching English Movie. (Thesis). Jakarta: Syarif Hidayatullah State Islamic University Jakarta.

Purbasari, F. (2017). Developing Listening Skill Using Video at the Twelve Grade of MAN 1 Purwodadi In 2016/2017 Academic Year. (Thesis). Surakarta Indonesia: Muhammadiyah University of Surakarta.

Riftiningsih, F. (2018). The The Use of Video Media to Improve Students' Listening Skill for The Second Grade Students of Senior High School in SMAN2 Grabag Magelang in Academic Year Of 2017/2018 A Graduating Paper. Thesis, Indonesia: Institute for Islamic Sladies Salatiga,

Rismawati. (2017). Teaching English by Using Authentic Videos. English Education Journal (EEJ), 8(2), 222-233.

Sugiyono. (2009). Metode Penelitian Kuantitatif, Kualitatif dan R\&D. Jakarta: CV. ALFABETA.

Susilowati, A. (2013). Improving the Tenth Grade Students' Listening Skill Using Videos at SMAN 4 Yogyakarta in the Academic Year of 2012/2013. Thesis, Yogyakarta Indonesia: State University of Yogyakarta, 2013.

Tyagi, B. (2013). Listening: An Important Skill and Its Various Aspects: The Criterion An International Journal in English ISSN 0976-8165, 01. 